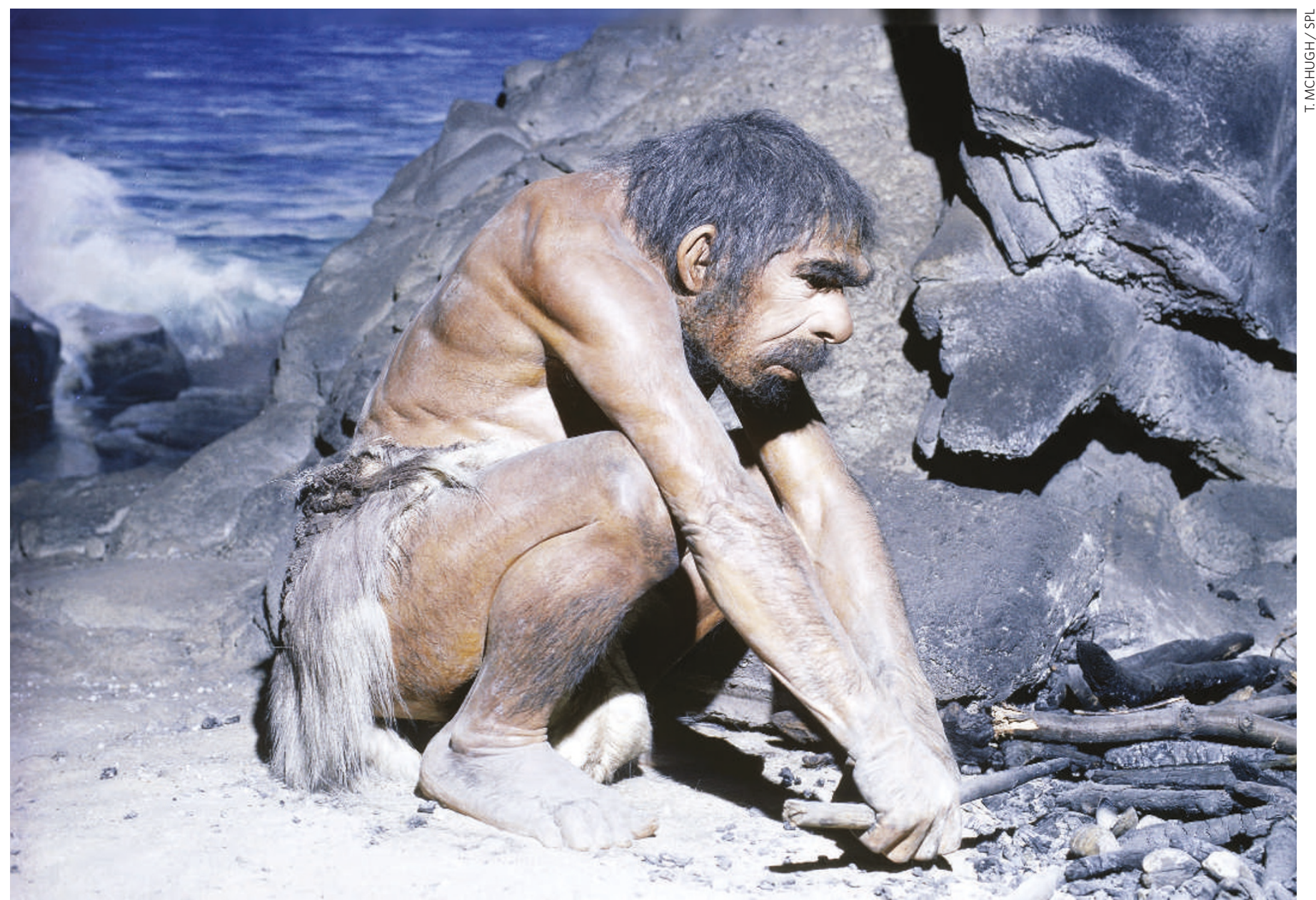

\title{
Decoding our cousins
}

\section{DNA extracted from bones could shed light on what happened when our ancestors crossed paths with Neanderthals. But not everyone can get the fossils out of the ground, as Rex Dalton learns.}

$\mathrm{n}$ the Moula-Guercy cave, nestled in a cliff overlooking France's verdant Rhône River valley, a bent Neanderthal finger bone pokes out of the ground, as if beckoning researchers. Not so long ago, the enticement might have been ignored. With palaeoanthropologists focusing instead on the most ancient branches of the human family tree, the study of Neanderthals - our closest relatives - was something of a backwater.

But now researchers are eager to comply with the come-hither gesture. A modern-day rush is on: for Neanderthal DNA.

Across Europe, researchers are scrambling to unearth fresh bones of Neanderthals that might yield intact genetic material. Spurred by recent discoveries of DNA segments in old bones, scientists are even laying plans to sequence an entire Neanderthal genome in the next two years.

This week, scientists are gathering in Bonn, Germany, to mark the 150th anniversary of the discovery of Homo neanderthalensis made in Germany's Neander Valley. During
21-26 July, experts will debate all aspects of Neanderthal life, from how they migrated across Europe to what effect climate may have had on their evolution.

At centre stage will be the future of DNA research and what it could tell us about the Neanderthals' relationship to modern humans. "Neanderthals split from the tree of human evolution about 400,000 years ago, just before the emergence of modern humans," says French archaeologist Jean-Jacques Hublin at the Max Planck Institute for Evolutionary Anthropology in Leipzig, Germany. "It is very important to understand in what respects genetically they are like us, and in what aspects they are different."

So far, the only closely related species with a mapped genome is the chimpanzee (Pan troglodytes $)^{1}$, whose ancestors diverged from those of humans about 7 million years ago. A Neanderthal genome could reveal much more about our recent evolutionary history.

The main difficulty is getting hold of genetic material. Few museum specimens of
Neanderthals have yielded DNA, and those that have could easily have been contaminated with modern human DNA. So fresh Neanderthal bones are prized possessions.

The hunt for bones is focused on the ridgelines and rugged valleys of southern France, where Neanderthals may have held out in their last refuge before going extinct about 28,000 years ago. They would have overlapped with Homo sapiens in this area for thousands of years - probably eventually losing out in the competition for resources.

\section{Out of bounds}

Alban Defleur of the Institute of Human Palaeontology in Paris hopes to return to the Moula-Guercy cave to find many more Neanderthal bones; it was here he unearthed evidence, published in a 1999 paper $^{2}$, that Neanderthals practised cannibalism at least 100,000 years ago. Today, the partially excavated site appears eerily frozen in time: tools are stacked about, strings marking quadrants sway from the ceiling, and a rubber bucket is 
placed over the finger bone that juts from the cave floor.

Shortly after Defleur published his paper, the cultural ministry office in nearby Lyon halted digging at the cave. Officials baulked at renewing Defleur's excavation permit, ostensibly because his collaborators had not filed a required sedimentology report on earlier digs. They filed it recently, saying the delay was to allow graduate students to finish their theses before details of the site were released in the report.

Some observers say in confidence that they think Defleur may have been snared in a web of nationalistic pride that overshadows French research. Co-authored with prominent US palaeoanthropologist Tim White, Defleur's article on cannibalism was published in the US journal Science, rather than in a French journal - a move that could have irritated some.

Other researchers have similarly fallen foul of government officials. In 1998, the same cultural ministry office that denied Defleur his permit was found by a French court to have forged documents. The forgery challenged the rights of the Chauvet cave's discoverer to data and photos; the nearby cave houses a world-famous display of rock art from this period.

\section{Close encounters}

In many respects, France has one of the richest histories in archaeology and palaeoanthropology. The University of Bordeaux I has been a worldwide magnet, with leading researchers coming to study the country's rich Neanderthal sites.

But now a team based in Germany is generating anxiety. The Max Planck institute plans to dedicate millions of euros to the 'Neanderthal Genome Project', an international collaboration that aims to sequence ten Neanderthal genomes in the next decade $^{3}$. The project is raising some eyebrows, however, among Francebased archaeologists, including Catherine Hänni, of the Superior Normal University of Lyon. "Are these true collaborations?" she asks. "Or do they just want the bone for DNA?"

Hublin, who used to work as an official at the main French research agency, the National Centre for Scientific Research (CNRS), understands the concerns. "The problem is a little like oil in an Arab country," he says. "I don't want to be too critical. But France is a closed world - at times not caring
"France is a closed world at times not caring about publishing in well-rated journals." Jean-Jacques Hublin about publishing in well-rated journals."

Meanwhile, Hublin continues to push on. As part of a large team involving principal investigators from France and other countries, he is working on a hillside outside the village of Jonzac, an hour's drive inland from Bordeaux in southwestern France.

A century ago near Jonzac, miners cutting a road to an underground limestone quarry unearthed Neanderthal artefacts. But these were left largely unexplored until about ten years ago, when French geologist Emile Marchais did some preliminary excavations. Later, in 2004, researchers from Bordeaux and the Max Planck institute began a more comprehensive excavation.

When the team arrived in June to open this summer's digging season, fields of red poppies bloomed around them. Nearby, workmen prepared to erect a barn-like steel structure to shelter the expanding excavations - an indication of the project's permanence. As tarpaulin was pulled away, sending spiders scrambling, an array of artefacts was revealed - including spear points, hand axes, scrapers and animal bones. Neanderthal material is so thickly layered here that a customized computer program is 㟒 needed to chart its recovery.

The artefacts are from the Mousterian group of Neanderthals that lived from about 250,000 to 35,000 years ago. The Mousterian survived in Europe at least until the first group of $H$. sapiens - the Aurignacian appeared, some 40,000 years ago. In some Jonzac sediments dated to about 36,000 years ago, tools from the Mousterian and the Aurignacian lie close together.

\section{Little to go on}

Archaeologists Shannon McPherron and Marie Soressi, both at the Max Planck institute, take detailed notes about where artefacts from these cultures merge. They will examine the layers, to see whether they have been shifted by a flood or by the collapse of a wall of rock. If so, determining what happened at this cultural interface will be doubly hard. Archaeologists prefer ordered sediments, which are identified and dated by the type of chipped stone tool or by the fossils of extinct animals found in them.

Shifting sediment layers also complicate the search for bone or teeth for DNA analysis. Homo remains found in jumbled sediments must be analysed with particular care to delineate Neanderthals from modern man. Ideally, McPherron notes, he would like to find Neanderthal and $H$. sapiens specimens embedded in wellordered sediments, showing they lived together. Such a find could provide ideal opportunities for genetic analysis - possibly showing that the two species interbred, an idea that has been long debated but never proven. Just definitively showing that Neanderthal and modern humans coexisted at the same location has been extremely difficult. "We really, really need to understand the geology of the site to make assertions about specimens," says McPherron.

Mysteriously, given the abundance of artefacts at Jonzac, Neanderthal fossils have been scarce there, and at the team's other French site - Roc de Marsal, 200 kilometres to the east. In two years, three teeth have been found at Roc de Marsal, and one tooth at Jonzac. The team was able to extract some collagen, or connective tissue, that could hold DNA. But McPherron says there is so little collagen that they are opting not to perform DNA analysis for fear of using it up. Instead, the team plans to test for stable isotopes such as carbon and nitrogen, which could offer glimpses into the diet and lifestyle of the Neanderthals.

Svante Pääbo, a Swede who directs the Max 


\section{THE CHANGING FACE OF NEANDERTHALS}

With only bones as a guide, artists have struggled for a century and a half to depict Neanderthals as they really lived. A few attempts over the years:

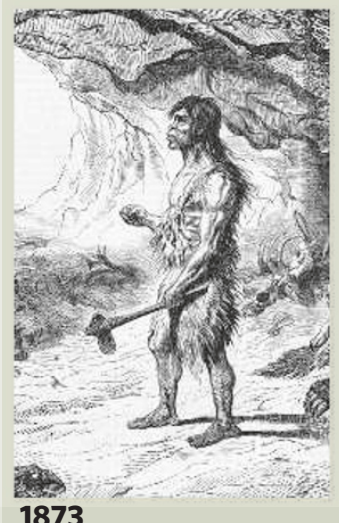

This illustration from Harper's Weekly was published less than 20 years after the species was discovered in Germany's Neander Valley.

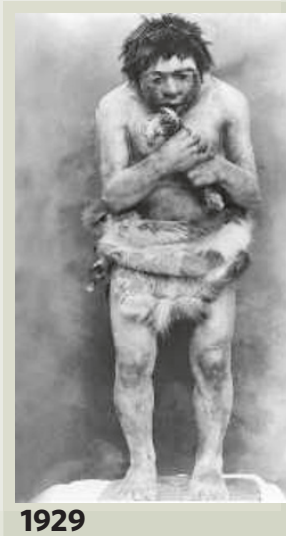

This model, one of several displayed at the Field Museum in Chicago, presented one of the first three-dimensional views of the creature.

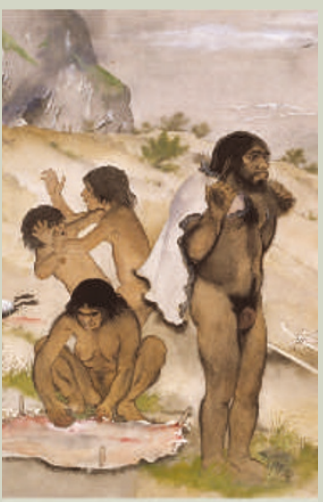

1950

Neanderthals are shown interacting with each other as a family in this painting from the Natural History Museum in London.

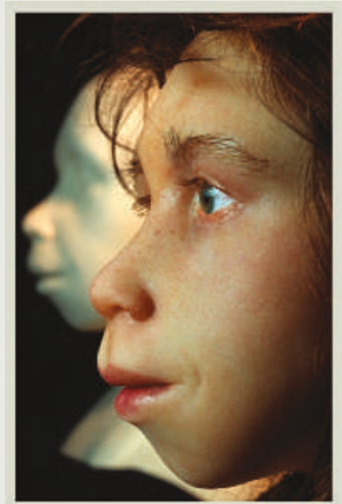

1999

A Neanderthal child from Gibraltar, perhaps as young as three at death, got a computer-generated makeover.

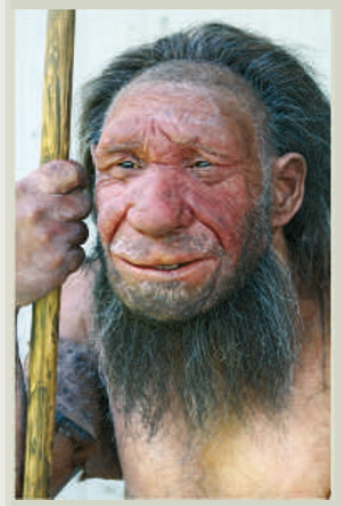

2006

The original Neanderthal specimen, which was discovered in 1856, comes to life in this reconstruction from the Neanderthal Museum in Germany.
Planck institute's research into palaeogenetics, is aching for more material for DNA analysis. In 1997, he published mitochondrial DNA sequences from Neanderthal remains ${ }^{4}$. But although mitochondrial DNA is more abundant than DNA in the nucleus of a cell, nuclear DNA provides a far more complete picture.

In May, Pääbo reported at a meeting at Cold Spring Harbor Laboratory in New York that his team had recovered and sequenced about 1 million base pairs of nuclear DNA from Neanderthal bones from Croatia. The work could provide clues about when certain disease-causing genes arose in evolution, and perhaps pin down the source of traits such as hair or skin colour.

This week in Bonn, Max Planck officials will unveil the institute's plans to sequence an entire Neanderthal genome. The project will extract the nuclear DNA from bones or teeth from both the first Neanderthal specimen discovered, from Germany, and the Croatia material. "Absolutely, I believe we can do this now," says Pääbo. But his team wants to develop new technologies to meet its eventual goal of sequencing the genomes of ten separate Neanderthals.

\section{Search of a lifetime}

The DNA bug has also bitten Defleur, who is seeking to collaborate with one of the genehunting teams. His group has already found dozens of fragments of Neanderthal bones at Moula-Guercy, representing at least six individuals, both juvenile and adult. "I think there are many more here," says Defleur. White, a palaeoanthropologist at the University of California at Berkeley, has excavated with Defleur from France to Ethiopia and says: "Defleur's high-quality excavation and recovery at Moula-Guercy rivals that of modern forensics."

A key advantage of the Moula-Guercy site is that the bones are well preserved - because of the cannibalism that removes the flesh and thus destructive bacteria. Long bones have been cracked open for the marrow, which may increase the likelihood that DNA will survive, says White, an authority on cannibalistic practices $^{5}$.

White suspects this may be why Pääbo was successful in sequencing DNA from the Croatia samples: because they were from a site, called Vindija, where cannibalism was practised.

Almost monthly, palaeogeneticists are pushing back the clock on the age of DNA extracted from Neanderthals and associated

\section{"Are these true collaborations? Or do they just want the bone for the DNA?" - Catherine Hänni}

mammals. The specimens from Vindija are roughly 38,000 years old, making them the oldest nuclear DNA yet extracted. Last month, Hänni reported the isolation of the oldest known Neanderthal mitochondrial DNA, at 100,000 years old, from the Scladina cave in Belgium $^{6}$. And earlier this month, a Spanishled team reported isolating 400,000-year-old mitochondrial DNA from a cave bear (Ursus deningeri) in the Atapuerca cavern complex in northern Spain; the same cave complex has produced nearly three dozen early Neanderthal specimens ${ }^{7}$.

These older specimens produce only very short genetic segments. There were 123 base pairs isolated from the Belgium site. Only 41 base pairs were found in the cave bear studies, led by Cristina Valdiosera of the Complutense University of Madrid. This is a far cry from the 3 billion base pairs that make up a $H$. sapiens or, presumably, a Neanderthal genome.
But the advances in DNA studies make Defleur think his time for finding more fossils has finally come. For more than 20 years, he has searched the French countryside for Neanderthal caves. In the early days, he worked from geological maps, checking certain limestone formations for caves. Elevations - that would have been high enough to provide protection, but not so high as to be hard to access when carrying game - were matched to the formations. Using these techniques, Defleur found new caves, a number of which held remains of Neanderthal life, and re-excavated shelters that had been left only partially examined.

Near the Chauvet cave, a rock shelter containing many lithics, called Ranc de l'Arc, is one such place probed by Defleur. "I would very much like a major excavation here," Defleur says. And there are other newly discovered caves, whose locations remain secret. These are likely to be rich sources of artefacts; some even have lithics and pottery on the cave floor.

For each journey to these dwellings, Defleur observes a moment of silence, seeming to commune with France's earliest residents. "These are places of spirit," he says. By next summer, he hopes, the government bureaucracy will have the spirit to allow him more Neanderthal discoveries.

Rex Dalton is a West Coast correspondent for Nature.

1. The Chimpanzee Sequencing and Analysis Consortium Nature 437, 69-87 (2005)

2. Defleur, A., White, T., Valensi, P., Slimak, L. \& CrégutBonnoure, E. Science 286, 128-131 (1999).

3. Dalton, R. Nature 441, 260-261 (2006)

4. Krings, M. et al. Cell 90, 19-30 (1997).

5. White, T. Prehistoric Cannibalism (Princeton Univ. Press, 1992).

6. Orlando, L. et al. Curr. Biol. 16, 400-402 (2006).

7. Valdiosera, C. et al. Biol. Lett. doi:10.1098/rsbl.2006.0515 (2006). 